(C) Copyright by Wydawnictwa Naukowe Instytutu Lotnictwa

\title{
NUMERICAL STUDY OF AN ISOTHERMAL SLUSH FLOW FOR AEROSPACE PROPULSION APPLICATIONS
}

\author{
Ruben Di Battista*, Maria Teresa Scelzo*, Maria Rosaria Vetrano** \\ *Environment and Applied Fluid Dynamics, von Karman Institute for Fluid Dynamics, \\ 72, Chaussée de Waterloo, 1640 Rhode Saint Genèse, Belgium \\ ** Department of Mechanical Engineering, Faculty of Engineering Science, KU Leuven, \\ 300 Celestijnenlaan, 3001 Leuven, Belgium \\ rubendibattista@gmail.com,mariateresa.scelzo@vki.ac.be,rosaria.vetrano@kuleuven.be
}

\begin{abstract}
Slushes are two-phase solid-liquid single-species cryogenic fluids that exhibit an increased density and a greater heat capacity with respect to the corresponding normal boiling point liquids. These promising features are of large interest for applications that exploit slush as a thermal fluid, like super magnets refrigeration, cryogenic cooling of bio-materials or air conditioning, and for aerospace systems that use slush fluids as fuel or oxidizer. Several programs in the frame of the research on Slush Hydrogen (SLH2) as a new-generation fuel for aerospace propulsion have been started in the past. This work was carried out in the framework of a VKI research activity promoted by the Predict ESA Technology Research Programme, to investigate experimentally and numerically the behavior of slush flows in a representative upper stage feeding line. In this paper, we present a simulation based on a granular two-fluid model on an isothermal solid liquid mixture (slurry) and a Nitrogen slush (SLN2) fluid flowing in a horizontal pipe. A finite-volumes discretization using the software library OpenFOAM was benchmarked against experimental and numerical literature data, to assess the accuracy of the code in predicting pressure drops along the pipe axis and solid particle distribution across the pipe diameter. Moreover, the effects of concentration and inlet velocity are investigated. We show that the numerical model fairly reproduces the literature data in terms of important aspects as the solid volume fraction distribution and the pressure drops, especially for high flow rates.
\end{abstract}

Keywords: fluid dynamics, space propulsion, multiphase flows, CFD, cryogenics, slush flows

\section{INTRODUCTION}

With substantial evolution of space industry that is fast moving from an agencies-centered business model to a public-private joint effort, aerospace systems are planned to undergo similar evolution in technology in order to achieve more reliable and more cost-effective solutions to face the coming 
engineering problems posed by opening up space frontiers to masses and privates. Current generation space systems, especially space access systems, are basically powered by reliable solutions developed during the '60s and '70s for the space race and hardened in more than 50 years of successful deployment. Next-generation space access, transportation and colonization technologies, though, requires more advanced designs. Slush flows are two-phase solid-liquid single-species cryogenic fluids that exhibit an increased density $(16.5 \div 18 \%$ [1] [2]) and a greater heat capacity $(15 \div 18 \%$ [1] [2] ) with respect to normal boiling point fluids. These promising features are of big interest for applications that exploit the slush as a thermal fluid, like super magnets refrigeration or air conditioning, and for aerospace systems that use slush fluids as fuel or oxidizer. Several programs in the frame of the research on SLH2 as a new-generation fuel for aerospace propulsion system have been started in the past and still continue to be performed in the present (National Aeronautics and Space Administration (NASA)'s National Space Plane (NASP), European Space Agency (ESA)'s Future European Space Transportation Investigations Programme (FESTIP) and Japan Aerospace eXploration Agency (JAXA) program for research on SLH2 are the most famous examples). As an example, for a Space Shuttle mission the quantitative benefits of using SLH2 instead of Normal-Boiling-Point Hydrogen (NBPH2) in terms of payload added mass are estimated in 10\% [1] (see Pic. 1). Another modern analysis on the possible employment of slush flow for new generation launchers presents even more optimistic outcomes [3]. In last years, thanks to the increase of the computational power of workstations, Computational Fluid Dynamics (CFD) has emerged has a feasible alternative to real-case (or scaled) testing. The intrinsic difficulty of operating cryogenic facilities suggests CFD as a valuable tool also in the frame of slush flows modelling. In literature, different examples of modelling strategies have been reported: Two-fluids model (2FM) Finite Difference Method (FDM) method [4], Euler-Lagrange (E-L) Finite Volume Method (FVM) [5], Euler-Euler (E-E) 2FM [6] . In this work, a E-E approach will be discussed.

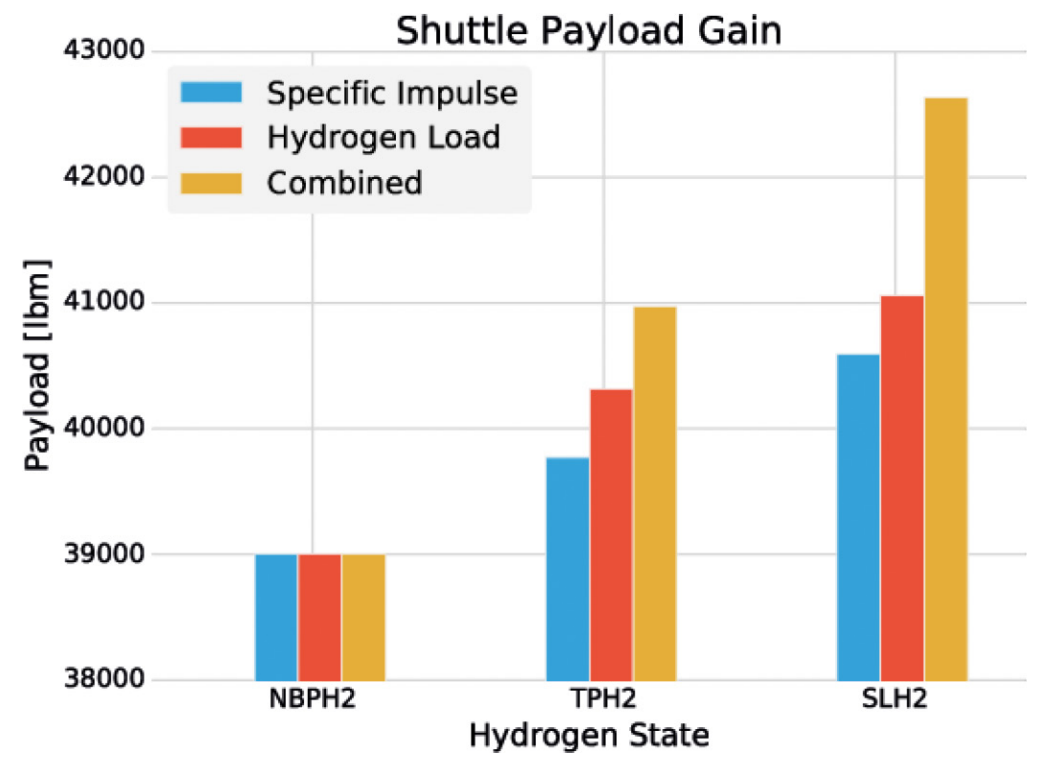

Pic. 1 Shuttle payload increase using SLH2 w.r.t. Normal Boiling Point H2 (NBPH2) and Triple-Point $\mathrm{H} 2$ (TPH2) 


\section{NUMERICAL MODEL}

In this work, a Euler-Euler FVM has been chosen, employed using the Free and Open Source Software (FOSS) library Open Source Field Operation And Manipulation (OpenFOAM) together with a Kinetic Theory for Granular Flows (KTGF) treatment of the solid particulate phase.

The flow equations are obtained with an averaging process after conditioning the local equations. Conditioning is obtained multiplying the equations by a phase indicator $\chi_{\varphi}(\mathrm{x}, \mathrm{t})$ function as expressed by Eq. 1 [7].

$$
\chi_{\varphi}=\left\{\begin{array}{rr}
1, & \text { if phase } \varphi \text { is present at }(x, t) \\
0, & \text { otherwise }
\end{array}\right.
$$

The resulting system of governing equations, after averaging, for incompressible flow, is shown in Eq. 2 and Eq. 3 [8],

$$
\begin{gathered}
\frac{\partial \alpha_{\varphi}}{\partial \mathrm{t}}+\boldsymbol{\nabla} \cdot\left(\alpha_{\varphi} \mathbf{U}_{\varphi}\right)=0 \\
\frac{\partial\left(\alpha_{\varphi} \mathbf{U}_{\varphi}\right)}{\partial \mathrm{t}}+\boldsymbol{\nabla} \cdot\left(\alpha_{\varphi} \mathbf{U}_{\varphi} \mathbf{U}_{\varphi}\right)=\boldsymbol{\nabla} \cdot\left(\alpha_{\varphi} \mathbf{R}_{\varphi}^{\text {eff }}\right)-\frac{\alpha_{\varphi}}{\rho_{\varphi}} \nabla p+\mathbf{M}_{\varphi}
\end{gathered}
$$

where $\alpha_{\varphi}$ is the -phase fraction, $U_{\varphi}$ is the velocity of phase, is the pressure of the flow, $R_{\varphi}^{\text {eff }}$ is the combined Reynolds and viscous stress, $M_{\varphi}$ is the inter-phase momentum exchange term.

Tab. 1 Momentum coupling terms

\begin{tabular}{ccc}
\hline & Standard & Phase Inversion \\
\hline $\bar{M}_{a}^{\text {drag }}$ & $\alpha_{a} \frac{3}{4} \frac{\rho_{b}}{d_{a}} C_{D}\left|\overline{\boldsymbol{u}_{r}}\right| \overline{\boldsymbol{u}_{\boldsymbol{r}}}$ & $\alpha_{a} \frac{3}{4}\left(f_{a} \frac{\rho_{b}}{d_{a}} C_{D}+f_{a} \frac{\rho_{b}}{d_{a}} C_{D}\right)\left|\overline{\boldsymbol{u}_{r}}\right| \overline{\boldsymbol{u}_{r}}$ \\
$\bar{M}_{a}^{l i f t}$ & $\alpha_{a} C_{L} \rho_{b} \overline{\boldsymbol{u}_{r}} \times\left(\nabla \times \overline{\boldsymbol{u}_{b}}\right)$ & $\alpha_{a} \alpha_{b} f_{a}\left(C_{L a} \rho_{b} \overline{\boldsymbol{u}_{r}} \times\left(\nabla \times \overline{\boldsymbol{u}_{a}}\right)\right)+\alpha_{a} \alpha_{b} f_{b}\left(C_{L b} \rho_{a} \overline{\boldsymbol{u}_{r}} \times\left(\nabla \times \overline{\boldsymbol{u}_{\boldsymbol{b}}}\right)\right)$ \\
$\bar{M}_{a}^{v \cdot m .}$ & $\alpha_{a} C_{v \cdot m} \rho_{b}\left(\frac{D_{b} \overline{\boldsymbol{u}_{b}}}{D t}-\frac{D_{a} \overline{\boldsymbol{u}_{a}}}{D t}\right)$ & $\alpha_{a} \alpha_{b}\left(f_{a} C_{v \cdot m \cdot a} \rho_{b}+f_{b} C_{v \cdot m \cdot b} \rho_{a}\right)\left(\frac{D_{b} \overline{\boldsymbol{u}_{b}}}{D t}-\frac{D_{a} \overline{\boldsymbol{u}_{a}}}{D t}\right)$ \\
\hline
\end{tabular}

$\mathrm{M}_{\varphi}$ represents an average term due to exchange of momentum between the two phases, its contribute is due to several phenomena (lift, drag, virtual mass, Basset force ...). In this work, only the drag and the virtual mass are considered whose expressions are reported in with two different formulations, one of them accounting for possible phase inversion effect (see Tab. 1).

Turbulence is modelled with a $\mathrm{k}-\epsilon$ approach for the liquid carrier phase (Eq. (4-5)),

$$
\begin{gathered}
\frac{\partial\left(\alpha_{\varphi} \mathrm{k}\right)}{\partial \mathrm{x}} \boldsymbol{\nabla} \cdot\left(\alpha_{\varphi} \mathbf{U}_{1} \mathrm{k}\right)-\boldsymbol{\nabla} \cdot\left(\frac{v_{\mathrm{t}}^{\text {eff }}}{\sigma_{\mathrm{k}}} \alpha_{\varphi} \rho_{\varphi} \nabla \mathrm{k}\right)=\alpha_{\varphi} \rho_{\varphi}(\mathrm{G}-\epsilon)+\mathrm{S}_{\mathrm{k}} \\
\frac{\partial\left(\alpha_{\varphi} \epsilon\right)}{\partial \mathrm{x}} \boldsymbol{\nabla} \cdot\left(\alpha_{\varphi} \mathbf{U}_{1} \epsilon\right)-\boldsymbol{\nabla} \cdot\left(\frac{v_{\mathrm{t}}^{\mathrm{eff}}}{\sigma_{\epsilon}} \alpha_{\varphi} \rho_{\varphi} \boldsymbol{\nabla} \epsilon\right)=\frac{\alpha_{\varphi} \rho_{\varphi} \epsilon}{\mathrm{k}}\left(\mathrm{C}_{1} \mathrm{G}-\mathrm{C}_{2} \epsilon\right)+\mathrm{S}_{\epsilon}
\end{gathered}
$$

where $G=2 \mu_{t} S_{i j} S_{i j}$ is a production term associated to the mean rate-of-strain tensor $S_{i j}$. 


\subsection{Solid Phase Treatment}

The Kinetic Theory for Granular Flows is a theory that extends the ideas and tools applied successfully for the kinetic theory of gases to flows that contain dispersed particles. The dispersed particles are treated statistically, characterized by a frequency distribution of velocities and collisions, and the fluctuating velocities are then related to the shear gradient. The final outcome [9] [10] of the application of this model to the granular flow is a transport equation (Eq. (6)) for a granular temperature $\Theta$. This temperature is associated to the random movement of particles whose diffusion coefficients are given by several different expressions obtained solving the collisional integrals, on the same spirit of the kinetic theory development of dense gases.

$$
\frac{3}{2}\left[\frac{\partial}{\partial x}\left(\alpha_{\varphi} \rho_{\varphi} \theta_{S}\right)+\nabla\left(\alpha_{\varphi} \rho_{\varphi} \theta_{S} \mathbf{U}_{S}\right)\right]=\left(-P_{S} \mathbf{I}+\boldsymbol{\tau}_{s}\right): \nabla \mathbf{U}_{\mathrm{S}}+\nabla \cdot\left(\kappa_{\Theta} \nabla \theta_{S}\right)-\gamma_{\theta}+\Phi_{\theta}
$$

In Eq. (6) is the granular pressure and it represents the normal forces acting on the solid phase due to particle interactions. $\tau \mathrm{S}$ is the stress tensor of the solid phase, $\kappa_{\Theta}$ is the granular conductivity, $\gamma_{\Theta}$ and $\Phi_{\Theta}$ are two terms that describe production and/or dissipation of granular energy. Expressions for all the terms can be further detailed in terms of, among the others, two parameters e and $\mathrm{d}_{\mathrm{p}}$, coefficient of restitution and particle diameter, whose specific derivations are not here reported. In highly packed zones of the domain that result in high $\alpha_{\mathrm{s}}$, additional stress due to particle sliding on each other must be accounted for as in Eq. (7).

$$
\begin{aligned}
& \mathrm{P}_{\mathrm{s}}=\mathrm{P}_{\text {kinetic }}+\mathrm{P}_{\mathrm{f}} \\
& \mu_{\mathrm{s}}=\mu_{\text {kinetic }}+\mu_{\mathrm{f}}
\end{aligned}
$$

A semi-empirical expression for the normal component of the frictional stress is given by [11] as shown in Eq. (8) whose frictional shear viscosity is expressed as in Eq. (9)

$$
\begin{gathered}
\mathrm{P}_{\mathrm{f}}=\mathrm{Fr} \frac{\left(\alpha_{\mathrm{s}}-\min \left(\alpha_{\mathrm{s}}\right)^{\mathrm{n}}\right.}{\left(\alpha_{\mathrm{smax}}-\alpha_{\mathrm{s}}\right)^{\mathrm{P}}} \\
\mu_{\mathrm{f}}=\mathrm{P}_{\mathrm{f}} \sin \delta
\end{gathered}
$$

being $\delta$ the angle of internal friction of the particle.

\subsection{Johnson and Jackson Boundary Conditions (BCs)}

The solid phase does not behave as the classical liquid on the walls, that means the classical no-slip condition that it is usually used on the walls for a liquid is not considered correct for a particulate. Instead, two different boundary conditions (for $\Theta$ and $\left.\mathrm{U}_{s}\right)$ ) on walls that allow non-zero velocities on the boundary as proposed in [11] are used in this work. They are derived with global balances of momentum and total energy over the control volume centered around the wall as shown in Pic. 2. Those BCs introduce two additional parameters, $\mathrm{e}_{\mathrm{w}}$ and $\varphi$, restitution coefficient and specularity coefficient, that are respectively the percentage of momentum normal to the wall conserved after collision and the percentage of tangential momentum lost due to friction against the wall. 


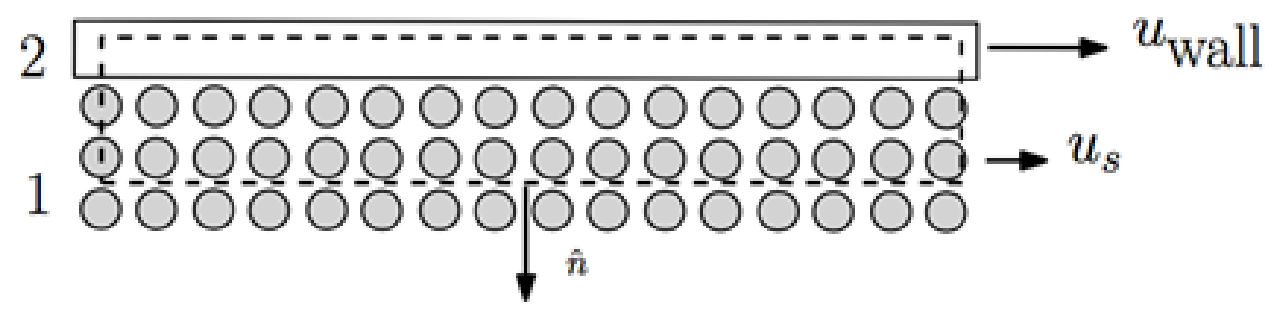

Pic. 2 Johnson and Jackson BC control volume

\section{NUMERICAL SETUP}

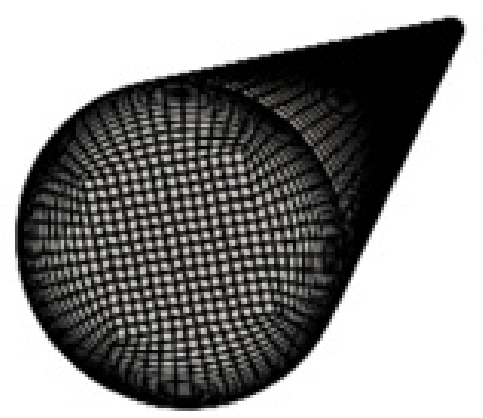

Pic. 3 Structured mesh of the pipe

To benchmark the numerical model presented in Sec. 2, we chose a typical cylindrical pipe geometry, for which we simulated two cases: a slurry case with glass beads and water and a proper Slush Nitrogen (SLN2) case. The computational domain has been meshed as shown in Pic. 3 with a structured grid, the cross section was composed by a central square region of $16 \times 16$ cells, and four circular sectors of $16 \times 14$ cells. The lengthwise dimension was divided in 500 cells achieving a total of 576000 cells. The grid was composed by three patches: inlet, outlet, walls for which the BCs that have been imposed are summarized in Tab. 2. On the walls $\mathrm{e}_{\mathrm{w}}=0.9, \varphi=0.01 \div 0.001$ while in the internal $\mathrm{e}=0.9$, $\alpha_{\max }=0.64$ (slurry), 0.5 (slush). For the KTGF several models can be chosen for granular viscosity, conductivity, granular pressure and frictional stress [10]. In these simulations Gidaspow and Syamlal models have been compared, a detailed description of those models can be found in literature [10]. The solver is an unsteady solver for which we fixed the Co number to a lower value to ensure stability of time integration, a backward implicit Euler integrator has been used. The concentration of the slurry/ slush into the carrier liquid has been set to $30 \%$ for both cases. The virtual mass coefficient $\mathrm{C}_{(\mathrm{v} . \mathrm{m} \text {.) }}$ has been set to 0.5 , no lift is considered. 
Tab. 2 Summary of Boundary Conditions

\begin{tabular}{llll}
\hline Field & Inlet & Outlet & Walls \\
\hline $\boldsymbol{\alpha}_{\boldsymbol{s}}$ & Fixed value & Zero gradient & Zero gradient \\
$\boldsymbol{\varepsilon}_{\boldsymbol{l}}$ & Mixing length law & Zero gradient & Wall function \\
$\boldsymbol{k}_{\boldsymbol{l}}$ & Turbulence intensity & Zero Gradient & Wall function \\
$\boldsymbol{v}_{\boldsymbol{t}}$ & Calculated & Calculated & Calculated \\
$\boldsymbol{v}_{\boldsymbol{t}}$ & Calculated & Calculated & Wall function \\
$p$ & Zero gradient & Fixed value & Zero gradient \\
$\boldsymbol{\Theta}_{\boldsymbol{p}}$ & Fixed value & Zero gradient & Johnson-Jackson BC \\
$\boldsymbol{u}_{\boldsymbol{s}}$ & $\left(0 u_{s_{y}} 0\right)$ & Zero gradient & Johnson-Jackson BC \\
$\boldsymbol{u}_{\boldsymbol{l}}$ & $\left(0 u_{l_{\boldsymbol{y}}} 0\right)$ & Zero gradient & No slip \\
\hline
\end{tabular}

\section{RESULTS}

CFD simulations have been performed on two different cases. One, more classical, of a slurry flow made by water and glass beads [12], the other of SLN2 slush [13].

\subsection{Water and glass beads}

\section{Sensitivity analysis on the Kinetic Theory for Granular Flows parameters}

In Sec. 2.1 the Kinetic Theory for Granular Flows is presented. This model is controlled by several parameters that can be modified and that can influence the results of the simulation. In the analyzed literature, some suggestions are given about few parameters, in particular the restitution coefficient and the specularity coefficient, both for walls bouncing and internal collisions: in [14] they are taken with the values of, respectively, $\mathrm{e}_{\mathrm{w}}=0.99 \mathrm{e}=0.9, \varphi=0.0001$ while in [15] $\varphi=0.02$. Moreover, a maximum packing limit for the phase fraction is given, , for slush nitrogen. It's clear as those parameters show a behaviour that is strongly case-specific. A summary of the different modifications done is summarized in Tab. 3 in terms of effects on the pressure drop along the pipe.

From the analysis of Tab. 3 is possible to understand how the most important parameter, in terms of influence over the pressure drop, is the specularity coefficient $\varphi$. This importance could be easily understood since $\varphi$ represents the amount in percentage of tangential momentum loss at the wall. As in a "normal" pure-liquid situation where the viscosity and the boundary layer that it is created near the wall influence the pressure loss, also here the wall interaction is very important even if the physical process that creates the momentum loss is not fully related to friction, but also to collisions of solid particles with the wall itself (see Sec. 2.1).

Pressure drop is not the only property of interest. Also, the distribution of the solid phase along the diameter in a cross-section and the velocity profile are interesting. A selection of cases is compared in terms of velocity profiles in Pic. 4 and in terms of phase fraction dispersion over the diameter in Pic. 5. 


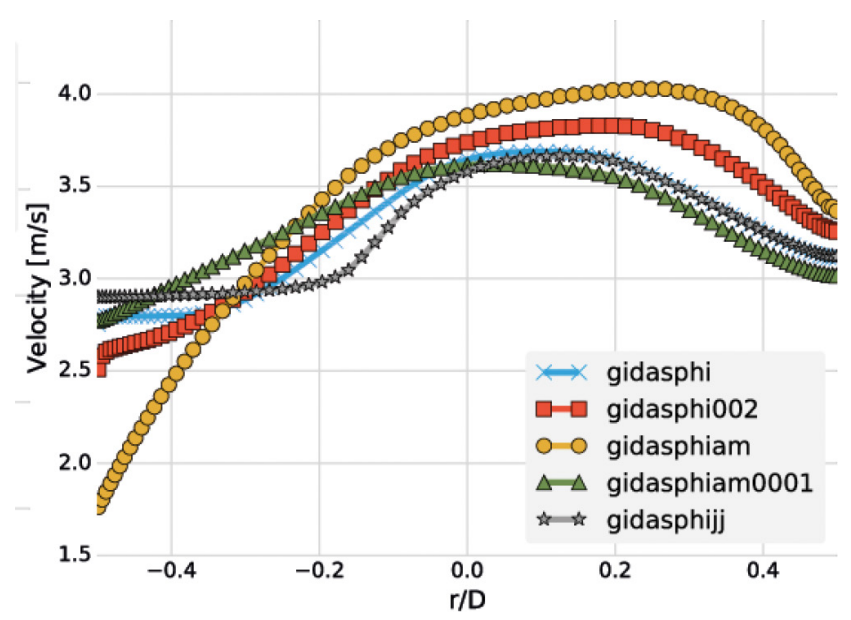

Pic. 4 Velocity profiles comparison for Gidaspow model

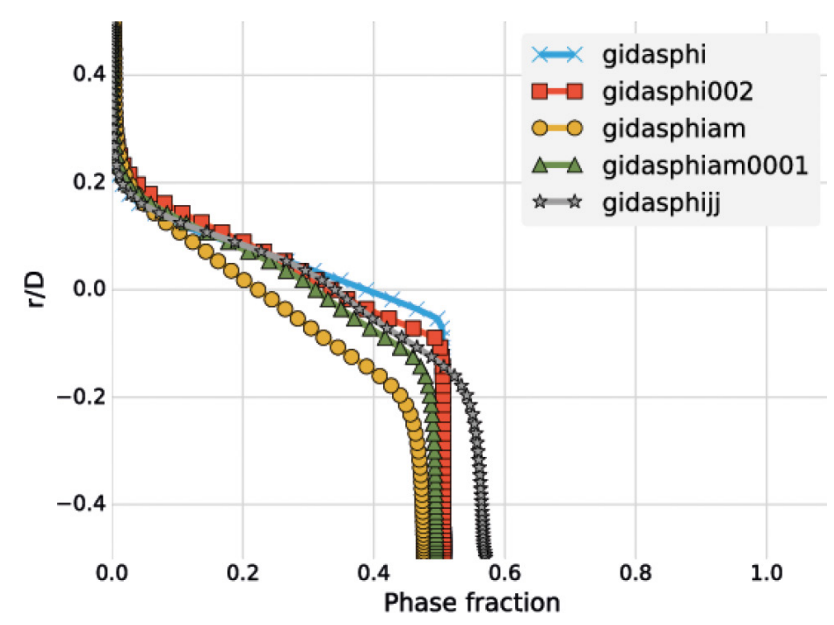

Pic. $5 \alpha$ profiles comparison for Gidaspow model

From the sensitivity analysis, we infer how the maximum packing limit $\alpha_{\max }$ and the radial model have a strong impact on the velocity profile in particular. The profile for the lower $\alpha_{\max }$ (gidasphiam) tends more to the typical profile of a pure liquid but the pressure drop is doubled with respect to the base case, leading to unrealistic values. This behavior can be hindered tweaking with the value of the specularity coefficient (gidasphiam0001), but the effect on the velocity profile is also reduced. Focusing the attention to the phase fraction profiles instead, the effects of the different packing limit are somehow lower, the shape of the $\alpha$ fraction is kept while changing all the parameters, with minor differences in the slope: the case that implements a different radial distribution function model (gidasji) shows a smoother slope passing from the zone of the pipe (on the bottom) with higher density of particles to the upper part that does not contain solids.

It is not possible to appreciate an evident difference between the two models, Syamlal's or Gidaspow's, that predict similar profiles in terms of phase fraction and velocity. The effect of the lower particle diameter is instead very clear: the smaller particles are more easily dragged by the carrier liquid 
resulting in a more homogeneously dispersed phase fraction profile related to a velocity profile that resembles the one of a pure liquid. Another effect to be highlighted due to the different particle size is an increase of the pressure drop, probably associated to the fact that in a control volume of the flow more particles can be contained leading to a higher frequency of collisions that in turn causes a loss of momentum and hence a higher pressure drop.

This case has been chosen since the shape of the particles is well established and spherical. The density ratio between solid and liquid phase is also quite high (2.4). The pipe diameter was set to $55 \mathrm{~mm}$. Pic. 6 show the result of the computations. As it is possible to appreciate, the quality of prediction in terms of solid fraction profile are in good agreement, especially with the Gidaspow model, with experimental data. In the case of pressure drop a pressure rise is experienced in the experiments, probably due to the deposition of particles and the formation of a bed on the bottom of the pipe with increase of frictional stress. This behavior is not predicted correctly by OpenFOAM also when frictional stress is explicitly accounted for as in Eq. (8). For higher flow rates that provide more homogeneous profile of particulate along the diameter, again Gidaspow model gives better predictions. The black line in Pic. 6-a is the result of an empirical correlation for sand flows [16]. In Tab. 4 a summary of simulations for this case is collected.
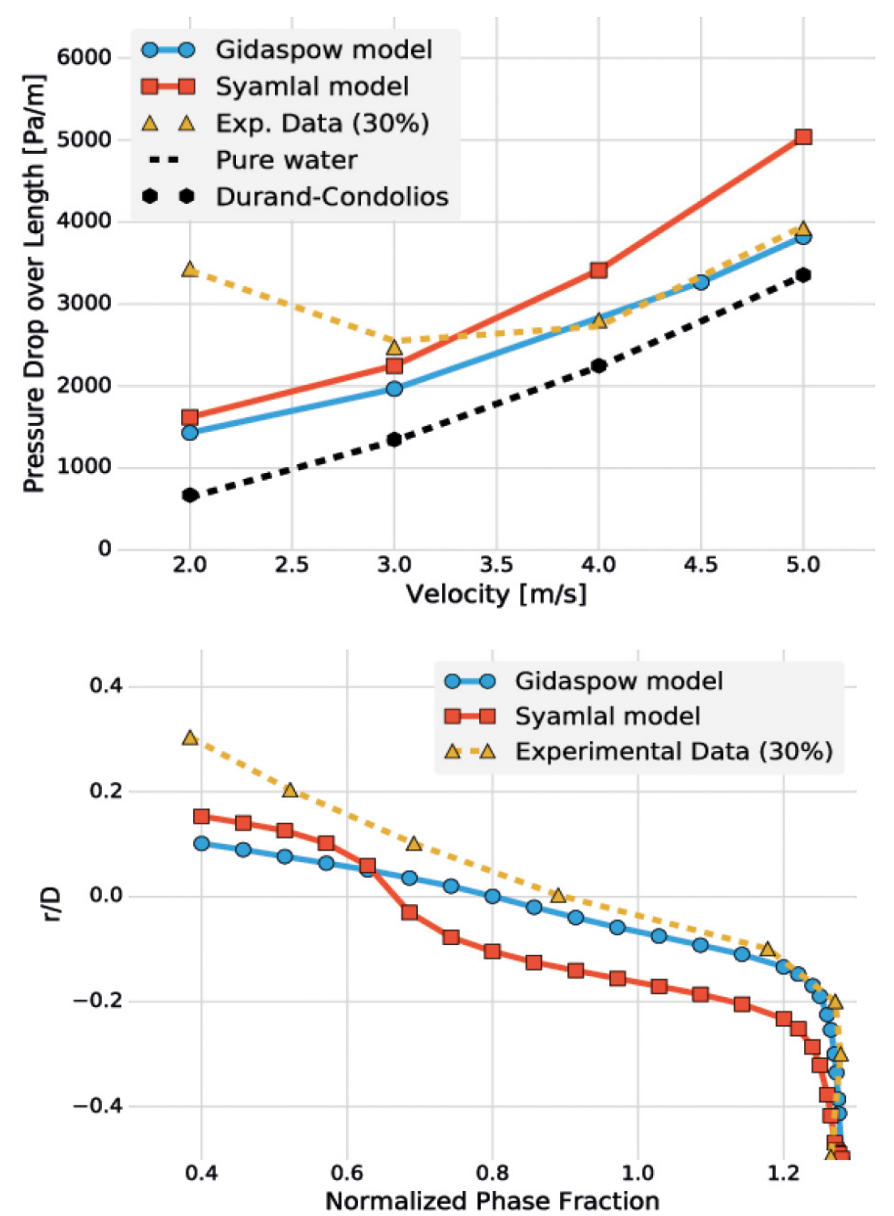

Pic. 6 Pressure drop ( $\mathrm{a}-$ left) and volume fraction (b-right) distributions for the glass beads case 


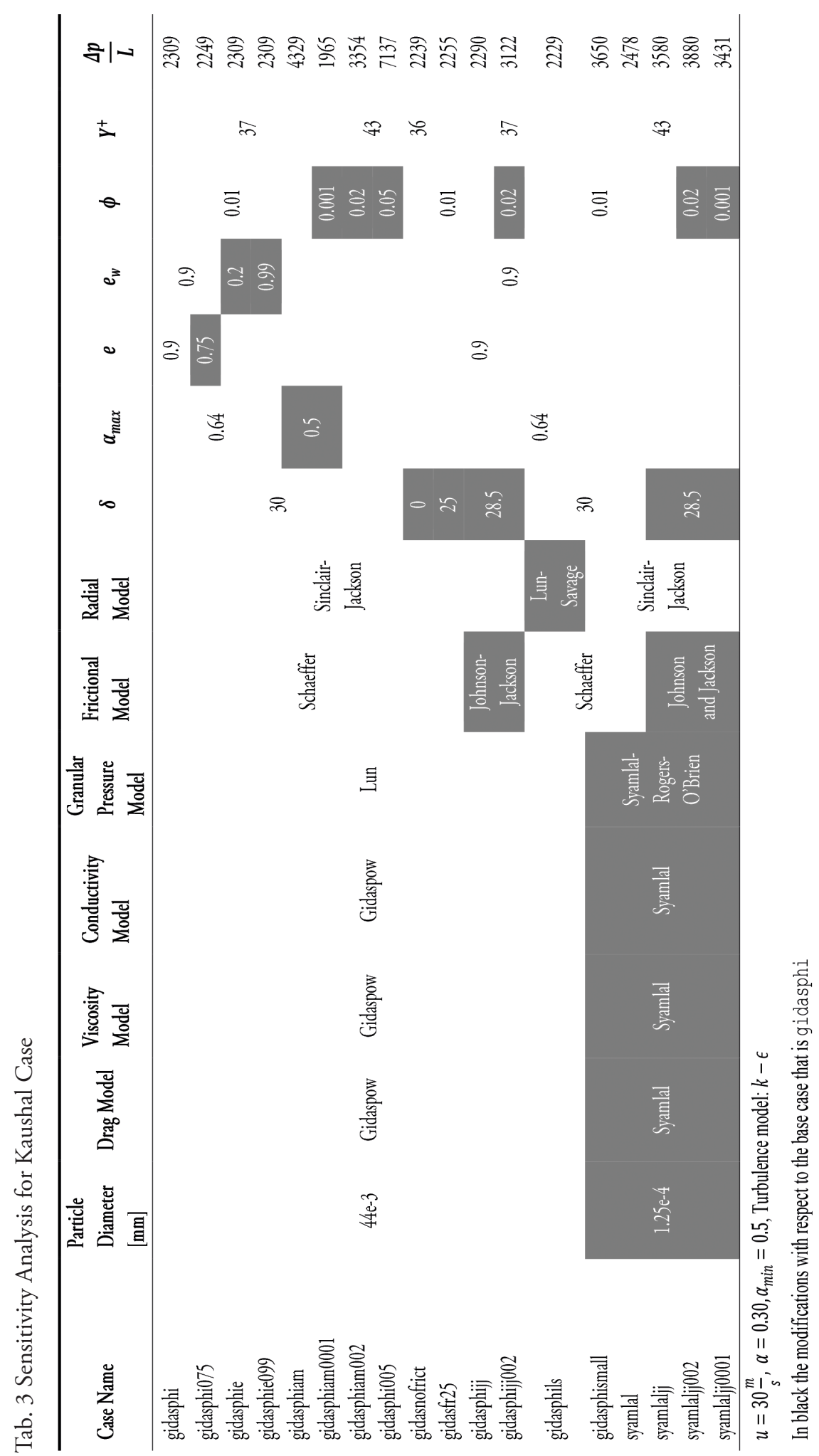




\subsection{SLN2}

In the case of proper slush flow, the diameter of the pipe has been shrunk to $15 \mathrm{~mm}$ in order to fit the same conditions of the benchmark case. In this case, moreover, the particles shape is not completely defined and the assumption made for drag and lift of spherical particles could reveal as a strong modelling assumption. Nonetheless Pics. 7-9 show the predicted profiles and properties for the case of slush. In Pic. 7 the accordance with experimental PIV data is satisfying, even if a small velocity defect of the experimental samples can be seen. This could be associated to the non-complete modeling of inter-phase momentum exchange with all the major contributions leading to defect in settling tendency estimation. Pic. 8 shows the effect of velocity over phase fraction distribution along the diameter. Increasing flow rate, as intuitively expected, creates a more homogeneous $\alpha_{s}$ distribution with minor deposition. In Pic. 9 we highlight the major effect of the specularity coefficient $\varphi$. The computed pressure drop curves overestimate or underestimate the pressure drops when changing the $\varphi$ value of one order of magnitude. The maximum error, however, for the range of velocities studied, is within $15 \%$ with respect to experimental data. An intermediate value of $\varphi$ (e.g. 0.05) is expected to be able to reduce the error.

All the commented results are also summarized in Tab. 5.

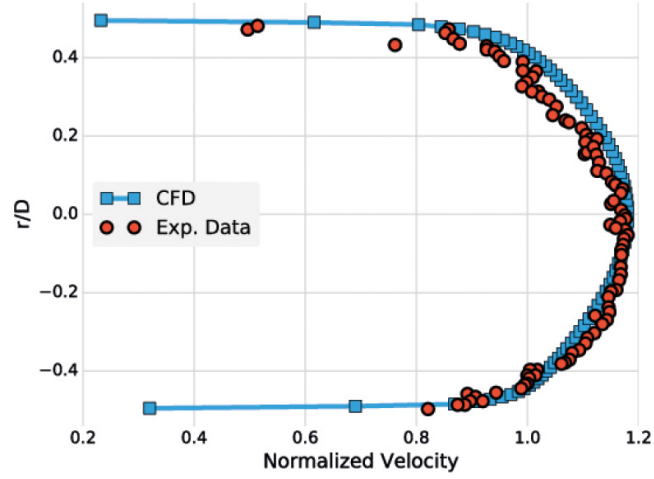

Pic. 7 Velocity profile for the slush case

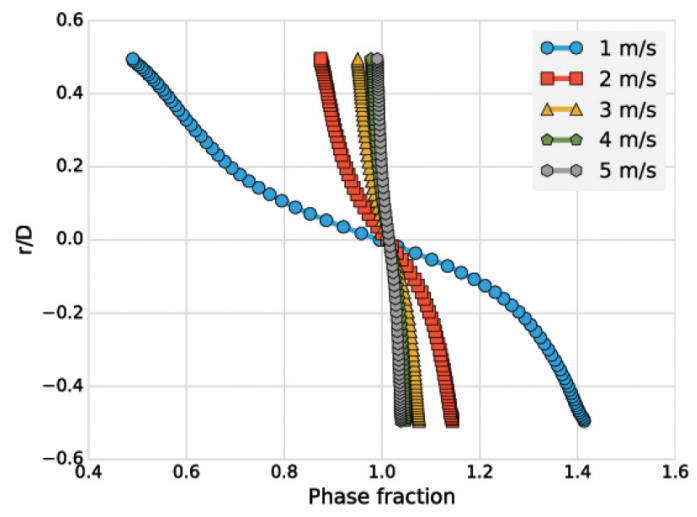

Pic. 8 Volume fraction profile for the slush case at different inlet velocities 


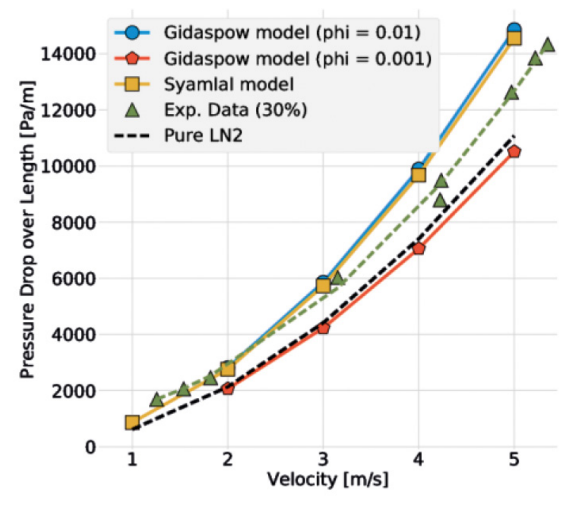

Pic. 9 Pressure drop profile for the slush case

\section{CONCLUSIONS AND FUTURE IMPROVEMENTS}

In the present work, the performance of a Finite Volume code based on the Two-fluid model with Eulerian treatment of solid phase has been presented for a cylindrical pipe geometry. The physical behavior and the macroscopic properties in the range of velocities and concentration analyzed are in reasonable agreement with chosen experimental benchmarks. Particularly the pressure drop, as also the velocity profile, are predicted with relatively low error for high flow rates, while, limited to the glass beads case, the pressure rise, that is thought to be driven by sedimentation on the pipe bed, is not replicated correctly. From the simulations, the major role of the specularity coefficient is strongly enforced, its current user-defined nature surely represents a topic of interesting future research. In particular, literature provides attempts of estimating that coefficient extracting information from the near-wall region [17] that could be implemented and studied in OpenFOAM thanks to its FOSS nature. Slush flows are interesting mostly because they provide enhanced thermal properties thanks to their intrinsic phase-changing nature. Future efforts should be put in the frame of modelling complete thermal and melting effects in order to build a useful tool for the conceptual design of new generation space systems. A paper on the simulation efforts for energy-enabled non-isothermal slurry flows is currently under preparation.

\section{ACKNOWLEDGMENTS}

The present work has been developed as a M.Sc. graduation thesis for the degree of Aeronautical Engineering at Politecnico di Milano in a joint partnership with VKI. The work has been funded by the scholarship

prize Borsa Tesi all'estero from Politecnico Di Milano and a Short Training Program scholarship from VKI. 
Tab. 4 Glass-beads case results summary

\begin{tabular}{|c|c|c|c|c|c|c|c|}
\hline Model & Velocity & $\boldsymbol{\delta}$ & $\alpha_{\max }$ & $e$ & $e_{w}$ & $\phi$ & $\frac{\Delta p}{L}$ \\
\hline \multirow{4}{*}{ Syamlal } & 1 & \multirow{10}{*}{28.5} & \multirow{10}{*}{0.5} & & \multirow{10}{*}{0.9} & \multirow{5}{*}{0.001} & 880 \\
\hline & 2 & & & & & & 1429 \\
\hline & 3 & & & & & & 1965 \\
\hline & 4.5 & & & & & & 3265 \\
\hline \multirow{6}{*}{ Gidaspow } & 5 & & & & & & 3821 \\
\hline & 1 & & & & & \multirow{5}{*}{0.01} & 775 \\
\hline & 2 & & & & & & 1619 \\
\hline & 3 & & & & & & 2248 \\
\hline & 4 & & & & & & 3413 \\
\hline & 5 & & & & & & 5038 \\
\hline
\end{tabular}

Tab. 5 Slush case results summary

\begin{tabular}{|c|c|c|c|c|c|c|c|}
\hline Model & Velocity & $\boldsymbol{\delta}$ & $\alpha_{\max }$ & $e$ & $e_{w}$ & $\phi$ & $\frac{\Delta p}{L}$ \\
\hline \multirow{5}{*}{ Syamlal } & 1 & & & & & & 1192 \\
\hline & 2 & & & & & & 3059 \\
\hline & 3 & & & & & & 5958 \\
\hline & 4 & & & & & & 9715 \\
\hline & 5 & 28.5 & 0.5 & & 0.9 & 0.01 & 14368 \\
\hline \multirow{4}{*}{ Gidaspow } & 2 & & & & & & 2817 \\
\hline & 3 & & & & & & 5860 \\
\hline & 4 & & & & & & 9888 \\
\hline & 5 & & & & & & 14858 \\
\hline
\end{tabular}

\section{BIBLIOGRAPHY}

[1] A. Friendlander, R. Zubrin and T. L. Hardy, "Benefits of slush hydrogen for space missions," Cryogenics, vol. 10, no. 5, pp. 372-380, 1970.

[2] C. Sindt, A summary of the characterization study of slush hydrogen, vol. 10, Cryogenics, 1970, pp. 372-380.

[3] Dumont, Etienne, Stappert, Sven, Ecker, Tobias, Wilken, Jascha, Karl, Sebastian, Krummen, Sven, Sippel and Martin, "Evaluation of Future Ariane Reusable VTOL Booster stages," in roceedings of the International Astronautical Congress, IAC. 68th International Astronautical Congress, Adelaide, (2017).

[4] J. Ishimoto and R. Ono, "Numerical study of the two-phase flow characteristics of slush nitrogen," Cryogenics, vol. 45, no. 4, pp. 304-316, 2005.

[5] P. Crivellari, L. del Monte and F. Gamma, "Computational fluidynamics of hydrogen for aerospace vehicles," in 35th Joint Propulsion Conference, Los Angeles, 1999.

[6] K. Ohira, A. Ota, Y. Mukai and T. Husono, "Numerical study of flow and heat-transfer characteristics of cryogenic slush fluid in a horizontal circular pipe (SLUSH-3D)," Cryogenics, vol. 52, no. 7, pp. 428-440, 2012.

[7] D. P. Hill, "The computer simulation of dispersed two-phase flow," University of London, 1998.

[8] H. Rusche, "Computational fluid dynamics of dispersed two-phase flows at high phase fractions," University of London, 2003.

[9] D. Gidaspow, Multiphase flow and fluidization: continuum and kinetic theory descriptions, Academic press, 1994. 
[10] B. G. M. van Wachem, "Derivation, implementation, and validation of computer simulation models for gas-solid fluidized beds.," 2000.

[11] P. C. Johnson and R. Jackson, "Frictional-collisional constitutive relations for granular materials, with application to plane shearing," Journal of fluid Mechanics, vol. 176, pp. 67-93, 1987.

[12] D. R. Kaushal and Y. Tomita, "Solids concentration profiles and pressure drop in pipeline flow of multisized particulate slurries.," International journal of multiphase flow, vol. 28, no. 10, pp. 1697 $1717,2002$.

[13] K. Ohira, K. Nakagomi and N. Takahashi, "Pressure-drop reduction and heat-transfer deterioration of slush nitrogen in horizontal pipe flow.," Cryogenics, vol. 51, no. 10, pp. 563-574, 2011.

[14] Y. Jiang and P. Zhang, "Numerical investigation of slush nitrogen flow in a horizontal pipe," Chemical engineering science, pp. 169-180, May 2012.

[15] Y. Jiang and P. Zhang, "Pressure drop and flow pattern of slush nitrogen in a horizontal pipe," AIChE journal, vol. 59, no. 5, pp. 1762-1773, May 2013.

[16] R. Durand and E. Condolis, Experimental investigation of the transport of solids in pipes, Deuxieme Journée de lhydraulique, Societé Hydrotechnique de France, 1952.

[17] T. Li and S. Benyahia, "Evaluation of wall boundary condition parameters for gas-solids fluidized bed simulations," AIChE Journal, vol. 53, no. 10, pp. 3624-3632, 2013.

\section{ANALIZA NUMERYCZNA IZOTERMICZNEGO PRZEPEYWU SLUSZU NA POTRZEBY ZASTOSOWAŃ W NAPĘDACH LOTNICZYCH I KOSMICZNYCH}

\section{Streszczenie}

Niejednorodna mieszanina fazy stałej i ciekłej tego samego składnika (ang. slush) jest dwufazową cieczą kriogeniczną która charakteryzuje się zwiększoną gęstością i pojemnością cieplną w porównaniu z odpowiadającymi im cieczami o normalnej temperaturze wrzenia. Te obiecujące właściwości wzbudzają duże zainteresowanie w aplikacjach wykorzystujących taką mieszaninę jako wymiennik ciepła, w zastosowaniach takich jak: chłodzenie supermagnesów, kriogeniczne chłodzenie biomateriałów lub klimatyzacja. W systemach kosmicznych mieszaninę fazy stałej i ciekłej (ang. slush), wykorzystuje się jako paliwo albo utleniacz. W przeszłości rozpoczęto kilka programów w ramach badań nad slush-em wodorowym (SLH2) jako paliwem nowej generacji dla napędów lotniczych i kosmicznych. Praca opisana w niniejszym artykule została wykonana w ramach działalności badawczej VKI wspieranej przez „Predict ESA Technology Research Programme”. Miała na celu zbadanie, za pomocą eksperymentu i symulacji numerycznych, zachowania przypływów slash-u w modelowej linii zasilania silnika górnego stopnia rakiety. W artykule przedstawiono, opartą na granularnym modelu, symulację przepływu izotermicznego w poziomej rurze dwóch cieczy: mieszaniny ciało stałe - ciecz (klasyczna zawiesina) i slash-u azotowego (SLN2). Użyto dyskretyzacji metodą objętości skończonych oraz programów z biblioteki OpenFoam, otrzymane wyniki zestawiono z danymi eksperymentalnymi i symulacyjnymi dostępnymi w literaturze. W szczególności zbadano jak dokładnie przybliżony model przewiduje spadek ciśnienia wzdłuż rury oraz dystrybucję stałych cząstek w przekrojach poprzecznych rury. Co więcej sprawdzono wpływ warunków 
brzegowych na wlocie (rozkładu koncentracji cząstek stałych w niejednorodnej mieszaninie oraz prędkości) na wyniki. Pokazano, że zastosowany model numeryczny wykazuje dobrą zgodność opublikowanym już danymi pod względem istotnych aspektów, takich jak udział objętościowy frakcji stałej oraz spadek ciśnienia wzdłuż rury, zwłaszcza dla dużego natężenia przepływu.

Słowa kluczowe: dynamika płynów, napęd kosmiczny, przepływy wielofazowe, kriogenika, przepływy niejednorodnej mieszaniny (ang. slush-u) 